\title{
Pengaruh Celebrity Endorser dan Brand Image Terhadap Keputusan Pembelian Produk Wardah pada Konsumen Mahasiswa
}

\author{
Dewi Rosita \\ Universitas Tidar, Magelang \\ Ivo Novitaningtyas \\ Universitas Tidar, Magelang
}

Email: ivo.novitaningtyas@untidar.ac.id

\begin{abstract}
Abstrak
Banyaknya produk kosmetik yang beredar di pasar berdampak pada meningkatnya persaingan antar industri kosmetik di Indonesia. Oleh karena itu, para perusahaan bersaing agar dapat menguasai pangsa pasarnya dan mengembangkan strategi pemasaran untuk meningkatkan keputusan pembelian konsumen. Penelitian ini bertujuan untuk menganalisis pengaruh celebrity endorser dan brand image terhadap keputusan pembelian produk kosmetik Wardah di kalangan mahasiswa. Penelitian ini menggunakan pendekatan kuantitatif dengan menyebarkan kuesioner kepada 175 responden sebagai sampel. Populasi dalam penelitian ini yaitu mahasiswa aktif Fakultas Ekonomi Universitas Tidar. Pengambilan sampel dilakukan berdasarkan metode purposive sampling dengan menetapkan jumlah sampel $10 \%$ dari total populasi. Data primer yang telah terkumpul dianalisis menggunakan analisis regresi linier berganda dengan aplikasi SPSS versi 25 . Hasil penelitian menunjukkan bahwa secara parsial dan simultan celebrity endorser dan brand image berpengaruh signifikan terhadap keputusan pembelian. Hasil ini memberikan implikasi bagi perusahaan kosmetik untuk menggunakan strategi celebrity endorser dan meningkatkan citra produknya sehingga diharapkan dapat meningkatkan keputusan pembelian konsumen terhadap produknya.
\end{abstract}

Kata Kunci: Brand Image, Celebrity Endorser, Keputusan Pembelian, Kosmetik, Mahasiswa

\section{Pendahuluan}

Pesatnya pertumbuhan dan perkembangan perekonomian khususnya dalam dunia bisnis telah menimbulkan persaingan antar perusahaan. Kondisi tersebut juga terjadi pada perusahaan yang menjadi produsen dari produk kosmetik. Oleh karena itu, perusahan dituntut untuk mengembangkan strategi pemasaran dalam menghadapi pesaing-pesaing yang muncul. Dengan mengembangkan strategi pemasaran, diharapkan perusahaan dapat menarik ataupun mempertahankan konsumennya.

Saat ini kosmetik sedang menjadi trend atau gaya hidup, dimana peminatnya tidak terbatas pada kaum wanita. Selain itu konsumen juga memiliki permintaan yang besar terhadap produk perawatan kulit (skincare), salah satunya remaja atau mahasiswa. Haryani \& Herwanto (2015) juga menjelaskan bahwa keinginan akan kecantikan dan daya tarik diyakini dapat mendorong mahasiswa untuk mengkonsumsi kosmetik. Lebih lanjut, mahasiswa cenderung memiliki gaya hidup konsumeris atau tingkat konsumsi yang tinggi (Yuliana, 2015). Mahasiswa cenderung berperilaku konsumtif untuk mengikuti perluasan mode yang sedang on demand seperti kosmetik sebagai bentuk perawatan diri dalam mengubah penampilannya. Mahasiswa juga merupakan kelompok segmen yang berpotensi besar bagi produsen karena 
mereka cenderung mudah terbujuk oleh iklan, dan mudah terpengaruh oleh teman sebayanya (Arief, 2017).

Kosmetik merupakan salah satu produk bagi tubuh manusia untuk membersihkan, merawat, mempercantik atau merubah penampilan seseorang. Pertumbuhan kosmetik lokal di Indonesia terus berkembang seiring dengan meningkatnya permintaan akan produk kosmetik. Data dari BPS menunjukkan bahwa kinerja industri kimia, farmasi dan obat tradisional mengalami pertumbuhan yang sangat pesat dengan peningkatan sebesar 5,59\% pada kuartal pertama tahun 2020. Bahkan pada saat pandemi Covid-19, kelompok manufaktur mampu memberikan kontribusi signifikan terhadap devisa negara dengan merealisasikan nilai ekspor US \$ 317 juta pada semester pertama tahun ini, meningkat 15,2\% dibandingkan periode yang sama di tahun lalu.

Banyaknya jenis kosmetik yang beredar di dalam dan luar negeri, mengakibatkan persaingan antar industri kosmetik di Indonesia semakin kompetitif. Oleh karena itu, perusahaan-perusahaan bersaing untuk menguasai pangsa pasarnya. Kosmetik yang tersebar luas di pasar Indonesia, antara lain yaitu Wardah, Emina, Purbasari, Viva dan lainnya. Dimana setiap merek memiliki jenis produk yang berbeda. Di bawah ini adalah data merek dari kategori kosmetik yang sering dicari dan diminta konsumen melalui Google pada tahun 2020.

Tabel 1. Data Total Pencarian Produk Kosmetik di Google.

\begin{tabular}{|l|r|}
\hline \multicolumn{1}{|c|}{ Brand } & Total Pencarian \\
\hline Wardah & 831 ribu \\
\hline Emina & 88 ribu \\
\hline Nature Republic & 69 ribu \\
\hline Purbasari & 62 ribu \\
\hline Make Over & 57 ribu \\
\hline Garnier & $47 \mathrm{ribu}$ \\
\hline Innisfree & 42 ribu \\
\hline Laneige & 38 ribu \\
\hline Viva & 33 ribu \\
\hline Trulum & 2,9 ribu \\
\hline
\end{tabular}

Sumber: $\underline{w w w . d i g i m i n d . i d}$

Tabel 1 menunjukkan bahwa total pencarian produk kosmetik di Google yang menduduki posisi pertama dengan jumlah pencarian terbanyak yaitu Wardah sebesar 831 ribu. Posisi kedua dengan total pencarian sebesar 88 ribu diduduki oleh Emina. Selanjutnya posisi ketiga yaitu Nature Republic dengan total pencarian sebesar 69 ribu dan disusul oleh Purbasari dengan total pencarian sebesar 62 ribu. Selanjutnya pada posisi kelima yaitu Make Over sebesar 57 ribu total pencarian, lalu Garnier sebesar 47 ribu, Innisfree sebesar 42 ribu total pencarian, Laneige dengan total pencarian sebesar 38 ribu, Viva sebesar 33 ribu, dan Trulum dengan total pencarian sebesar 2,9 ribu.

Wardah merupakan merek kosmetik lokal yang diproduksi oleh PT Paragon Technology and Innovation. Wardah identik dengan berhijab, dan tagline Wardah adalah kosmetik halal sehingga target pemasarannya diperuntukkan bagi wanita muslimah. Walaupun demikian, para wanita non-muslim pun juga bisa memakainya. Wardah juga menawarkan keunggulan antara lain harga terjangkau, bahan yang digunakan berkualitas dan aman serta halal. Wardah menawarkan berbagai produk seperti body care, skin care, hand care, kosmetik dan parfum bagi konsumen. Dalam menghadapi persaingan yang ada, perusahaan-perusahaan kosmetik 


\section{Dewi Rosita, Ivo Novitaningtyas}

melakukan berbagai inovasi dengan mengeluarkan produk-produk baru. Melalui produk baru tersebut, Wardah memerlukan strategi pemasaran untuk memperkenalkan produk baru kepada konsumennya agar dapat memperluas jangkauan pemasaran dan meningkatkan daya saing serta lebih dikenal oleh konsumen. Dalam hal ini, Wardah menggunakan celebrity endorser sebagai salah satu bentuk strategi pemasaran untuk membantu mempromosikan dan mengiklankan produk tersebut. Celebrity endorser Wardah antara lain Dewi Sandra, Inneke Koesherawati, Natasha Rizky, Dian Pelangi, dan Zaskia Sungkar. Selain itu, Wardah juga bekerja sama dengan influencer asal Korea Selatan yang bernama Ayana Jihye Moon sebagai celebrity endorser.

Saat ini, celebrity endorser cenderung banyak digunakan oleh produk-produk kosmetik sebagai sarana promosi produk kepada konsumen. Hal tersebut karena selebritis dianggap sebagai ikon yang sangat dikenal masyarakat dan dapat mempengaruhi perilaku konsumen. Endorser biasanya menjadi bintang iklan yang dapat mendukung produk untuk mempengaruhi pikiran konsumen dalam mengambil keputusan pembelian. Penggunaan celebrity endorsement merupakan bentuk promosi yang dilakukan perusahaan dalam hal periklanan untuk meningkatkan penjualan dan branding agar diketahui banyak konsumen (Priyono, 2015). Celebrity endorser juga berpotensi mempengaruhi minat pelanggan sehingga dapat meningkatkan penjualan produk (Bramantya \& Jatra, 2016).

Brand image dijelaskan sebagai persepsi merek yang ada di benak konsumen. Brand image atau disebut juga citra merek memiliki peranan penting dalam mempengaruhi perilaku konsumen (Priyono, 2015). Merek yang memiliki citra yang lebih baik dapat mencerminkan kualitas produk yang lebih baik di mata konsumen (Negara, Arifiin, \& Nuralam, 2018). Saat melakukan pembelian, konsumen cenderung memilih merek dengan citra yang baik atau positif. Sebelum melakukan pembelian, konsumen juga cenderung mencari informasi mengenai merek yang bagus. Citra merek yang bagus bukan hanya dapat menarik pelanggan, tetapi juga dapat berkontribusi pada peningkatan keunggulan kompetitif. Brand image memainkan peran penting dalam meningkatkan minat pelanggan pada produk yang ditawarkan perusahaan (Bramantya \& Jatra, 2016). Dengan demikian, brand image dipertimbangkan sebagai variabel yang diduga akan mempengaruhi keputusan pembelian pada produk kosmetik Wardah.

Penelitian terdahulu telah membuktikan bahwa terdapat pengaruh antara variabel brand image dan celebrity endorser terhadap keputusan pembelian (Dewi, 2019). Hasil tersebut juga didukung oleh penelitian Heda (2017) yang menjelaskan bahwa celebrity endorser maupun citra merek memiliki pengaruh positif yang signifikan terhadap keputusan pembelian. Walaupun demikian, hasil berbeda ditunjukkan oleh penelitian Rizky \& Ilhami (2018) yang menyatakan bahwa celebrity endorser tidak memiliki pengaruh dalam pengambilan keputusan pembelian. Perbedaan tersebut juga ditunjukkan oleh hasil penelitian Novianti (2020) yang menjelaskan bahwa celebrity endorser tidak berpengaruh signifikan secara parsial terhadap keputusan pembelian. Dengan demikian, masih ada kesenjangan antara hasil dari penelitian terdahulu yang berkaitan dengan hubungan antar variabel dalam penelitian ini. Berdasarkan kondisi tersebut, maka diperlukan penelitian lebih lanjut untuk mengetahui hubungan antara variabel celebrity endorser, brand image dan keputusan pembelian khususnya pada produk kosmetik Wardah.

Penelitian ini perlu dilakukan untuk menganalisis dan mengetahui bagaimana pengaruh penggunaan celebrity endorser dan brand image terhadap keputusan pembelian produk Wardah di kalangan mahasiswa. Hasil penelitian diharapkan dapat memberikan manfaat baik secara teoretis maupun praktis. Hasil penelitian dapat menjadi referensi bagi penelitian selanjutnya. Selain itu, hasil diharapkan dapat memberikan implikasi manajerial bagi produsen atau perusahaan kosmetik khususnya Wardah untuk mengetahui bagaimana pengaruh celebrity 
endorser dan brand image terhadap pengambilan keputusan pembelian produk Wardah. Dengan demikian, perusahaan dapat menyusun strategi pemasaran yang sesuai dalam penggunaan celebrity endorser dan strategi peningkatkan citra merek, dalam rangka meningkatkan keputusan pembelian oleh konsumen terhadap produknya.

\section{Landasan Teori}

\section{Celebrity Endorser}

Celebrity endorser adalah selebritis, entertainment, tokoh masyarakat atau public figure yang berperan dalam periklanan untuk mempromosikan produk perusahaan guna mempengaruhi konsumen dalam keputusan pembelian (Bramantya \& Jatra, 2016). Celebrity endorser cenderung memberikan daya tarik bagi konsumen sehingga mempengaruhi keputusan pembelian konsumen. Penampilan menarik, perilaku baik atau karakteristik pribadi lainnya dapat meningkatkan kepercayaan konsumen dalam mengambil keputusan pembelian dan mempengaruhi penjualan produk. Semakin popular selebriti dan semakin banyak penggemarnya maka akan semakin mudah untuk mempromosikan produk agar dapat dikenal dan diminati oleh konsumen. Secara tidak langsung orang yang mengidolakan tokoh selebriti tersebut akan mencari tahu dan mengikuti perkembangan yang terjadi pada idolanya, begitu juga produk-produk yang digunakan oleh idolanya. Selain itu, ada juga kecenderungan konsumen untuk mengikuti gaya hidupnya seperti produk apa yang digunakan oleh idolanya atau sekedar membeli produk yang dipromosikan oleh tokoh idolanya. Dengan demikian, celebrity endorser dapat digunakan untuk meningkatkan penjualan produk dan juga meningkatkan brand awareness. Ada tiga indikator dalam mengukur celebrity endorser diantaranya yaitu daya tarik (attractiveness), kepercayaan (trustworthiness), dan keahlian (expertise) (Sintani, 2016). Daya tarik ini meliputi fisik, kecerdasan, kepribadian, dan gaya hidup ataupun karakteristik tertentu yang dimiliki oleh celebrity endorser dan dapat menarik perhatian konsumennya. Kepercayaan merupakan integritas dan kredibilitas celebrity endorser untuk dapat meyakinkan orang lain dalam membuat keputusan dan mengambil tindakan pembelian. Adapun keahlian terdiri dari pengetahuan, keterampilan, atau pengalaman yang berkaitan dengan subjek iklannya.

\section{Brand Image}

Brand image atau citra merek diartikan sebagai persepsi konsumen tentang merek yang muncul dalam pikiran mereka ketika mengingat sebuah merek (Fitrianna \& Aurinawati, 2020; Schiffman \& Kanuk, 2008). Merek memiliki ciri khas atau identitas tersendiri yang mampu membedakan produk satu dengan produk lainnya, walaupun jenis produknya sama. Perusahaan dapat mempertahankan brand image dengan terus melakukan inovasi dalam hal teknologi, menciptakan keunggulan dan ciri khas dari produk, menetapkan harga bersaing dan melakukan promosi yang tepat sasaran (Tjiptono \& Chandra, 2017). Semakin bagus brand image perusahaan semakin tinggi pengaruhnya terhadap keputusan pembelian konsumen (Kotler \& Keller, 2018). Bramantya \& Jatra (2016) menjelaskan bahwa citra merek yang positif dapat meningkatkan kepuasan sehingga mempengaruhi keputusan pembelian konsumen. Oleh karena itu, dengan membentuk citra merek bukan hanya mempengaruhi konsumen dalam memenuhi kebutuhannya, tetapi juga dapat memaksimalkan kepuasan konsumen. Citra merek yang bagus akan menjadi pedoman bagi konsumen ketika mengambil keputusan pembelian karena telah memiliki merek dengan citra yang baik. Selain itu juga memudahkan konsumen dalam melakukan pembelian karena tidak memerlukan waktu yang lama untuk membandingkan kembali produk satu dengan produk lainnya. Citra merek dapat diukur menggunakan beberapa indikator antara lain kekuatan (strengthness), keunikan (uniqueness), 


\section{Dewi Rosita, Ivo Novitaningtyas}

dan keunggulan (favorable) (Heda, 2017). Kekuatan mengacu pada atribut fisik yang dianggap lebih unggul dari merek lain dan bukan merupakan keunggulan yang dimiliki merek lain seperti tampilan fitur produk, keberadaan produk, harga produk, jangkauan pasar yang luas, dan fitur pendukung produk lainnya. Keunikan dijelaskan sebagai ciri khas suatu merek yang dapat dijadikan sebagai pembeda merek satu dengan merek lainnya. Misalnya perbedaan tampilan fisik produk atau nama merek yang mudah diingat, perbedaan harga produk, dan perbedaan layanan yang diberikan dari sebuah produk. Adapun keunggulan mengacu pada kemampuan merek agar mudah diucapkan dan diingat konsumen sehingga dapat membuat merek tersebut terkenal atau menjadi merek favorit di masyarakat.

\section{Keputusan Pembelian}

Keputusan pembelian adalah proses dimana konsumen memilih suatu tindakan dari beberapa alternatif pilihan yang telah didasarkan pada pertimbangan-pertimbangan tertentu untuk membeli suatu barang atau jasa dalam memenuhi keinginan dan kebutuhannya (Schiffman \& Kanuk, 2008). Persepsi konsumen juga dapat berpengaruh dalam membentuk keputusan pembelian untuk membeli produk atau tidak. Ketika konsumen menganggap produk itu bagus, bermutu, berkualitas, dan terpercaya maka dapat mempengaruhi keputusan pembelian. Dengan adanya celebrity endorsement dan brand image yang baik yang baik dapat berdampak besar pada cara konsumen memandang produk tersebut. Tahapan dalam melakukan keputusan pembelian diantaranya yang pertama pengenalan kebutuhan dan keinginan, kedua pencarian informasi, ketiga evaluasi terhadap alternatif pembelian, tahap yang keempat keputusan pembelian, dan yang terakhir tingkah laku setelah pembelian (Kotler \& Keller, 2018; Nurhalim, 2021). Oleh karena itu, pembeli perlu membuat keputusan mengenai apa yang akan dibeli, apakah harus membeli, kapan akan membeli, di mana harus membeli, dan bagaimana menggunakannya. Keputusan pembelian juga dijelaskan sebagai kondisi dimana konsumen memilih diantara beberapa alternatif sehingga pada akhirnya konsumen tersebut dapat memutuskan produk mana yang akan dibeli (Ahmadi et al., 2018). Dengan demikian, dapat diambil kesimpulan bahwa keputusan pembelian merupakan tahapan pilihan konsumen ketika konsumen membuat keputusan untuk memenuhi kebutuhannya atau membeli suatu produk. Menurut Kurniawan (2018) ada beberapa indikator keputusan pembelian diantaranya yaitu (1) Sesuai dengan kebutuhan dan keinginan konsumen, (2) Pembelian karena kualitas produk, (3) Pembelian karena terpengaruh celebrity endorser, dan (4) Pembelian karena citra merek yang dimiliki.

\section{Pengembangan Hipotesis}

\section{Pengaruh Celebrity Endorser Terhadap Keputusan Pembelian}

Persepsi konsumen tentang produk berdampak pada keputusan pembelian konsumen. Jika suatu produk memiliki mutu yang baik, berkualitas, dan dapat dipercaya maka bisa dikatakan baik. Celebrity endorsement memiliki pengaruh yang signifikan dalam membentuk persepsi atau cara konsumen memandang suatu produk melalui iklan (Dewi, 2019). Dengan adanya celebrity endorsers maka pesan dari iklan tersebut akan semakin mudah diterima konsumen, sehingga semakin baik celebrity endorsers yang digunakan maka akan semakin mempengaruhi keputusan pembelian konsumen (Heda, 2017). Berdasarkan uraian tersebut maka dapat dirumuskan hipotesis sebagai berikut:

$\boldsymbol{H}_{1}$ : Celebrity endorses berpengaruh positif terhadap keputusan pembelian 


\section{Dewi Rosita, Ivo Novitaningtyas}

\section{Pengaruh Brand Image Terhadap Keputusan Pembelian}

Brand image dapat mencerminkan penilaian konsumen terhadap karakteristik produk, sehingga brand image yang bagus mampu memberikan perngaruh kepada sikap konsumen saat mengambil keputusan pembelian (Heda, 2017). Dalam menghadapi persaingan bisnis yang kompetitif, perusahaan harus terus menerus mentranformasikan produknya dalam menciptakan citra merek atau brand image yang bagus dibenak konsumen (Schiffman \& Kanuk, 2008). Oleh karena itu, dengan adanya brand image yang baik bisa meningkatkan keputusan pembelian terhadap suatu produk yang citranya baik dibandingkan dengan kompetitornya menurut konsumen. Berdasarkan uraian tersebut maka dapat dirumuskan hipotesis sebagai berikut: $\boldsymbol{H}_{2}:$ Brand image berpengaruh positif terhadap keputusan pembelian

\section{Kerangka Penelitian}

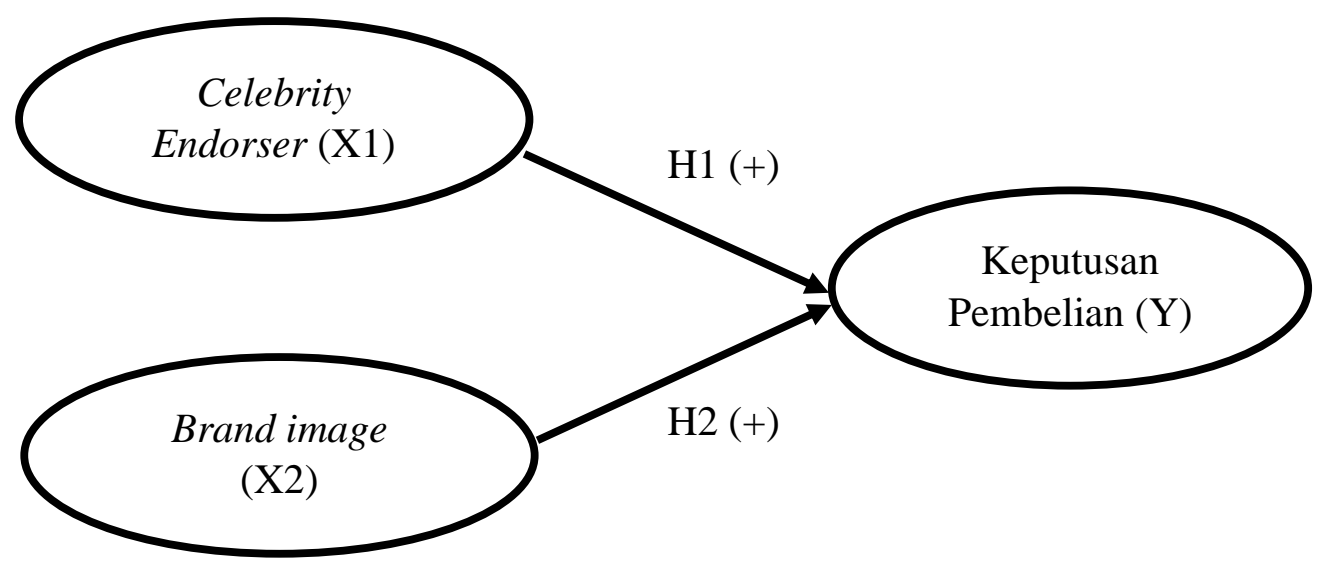

Gambar 1. Kerangka Penelitian

\section{Metode Penelitian}

Penelitian ini menggunakan pendekatan metode kuantitatif untuk mengetahui pengaruh celebrity endorser dan brand image terhadap keputusan pembelian Wardah pada mahasiswa di Fakultas Ekonomi Universitas Tidar. Sumber data yang digunakan dalam penelitian ini berupa data primer, dimana informasi dari data primer diperoleh melalui sumber primer dengan membagikan link kuesioner dalam bentuk google form kepada mahasiswa sebagai responden. Skala pengukuran yang digunakan dalam penelitian ini berupa skala likert dengan 4 pilihan skala yaitu sangat tidak setuju, tidak setuju, setuju, dan sangat setuju. Skala likert ini merupakan alat ukur yang digunakan untuk mengukur data penelitian berdasarkan sikap, perilaku dan persepsi seseorang ataupun kelompok.

Populasi penelitian ini yaitu mahasiswa aktif Fakultas Ekonomi Universitas Tidar sebanyak 1735 orang. Teknik pengambilan sampel penelitian ini adalah teknik NonProbability Sampling yang dilakukan dengan cara purposive sampling atau pengambilan sampel berdasarkan pada parameter yang ditetapkan sebelumnya. Adapun kriteria tersebut diantaranya sebagai berikut (1) mahasiswa aktif Fakultas Ekonomi Universitas Tidar, dan (2) pernah menggunakan produk Wardah. Apabila populasi kurang dari 100 responden maka sampel diambil secara keseluruhan. Sementara itu, apabila populasi lebih dari 100 responden maka sampel yang diambil sekitar 10\% - 15\% atau lebih (Sugiyono, 2013). Adapun, jumlah sampel yang digunakan dalam penelitian ini yaitu sebanyak 175 mahasiswa atau $10 \%$ dari total populasi. Jumlah ini dianggap memenuhi jumlah sampel yang digunakan dalam penelitian yaitu antara 30-500 (Sekaran, 2003). 


\section{Variabel Penelitian dan Definisi Operasional}

Penelitian ini menggunakan variabel bebas dan variabel terikat. Variabel bebas dalam penelitian ini adalah celebrity endorser (X1) dan brand image atau citra merek (X2), sedangkan variabel terikatnya yaitu keputusan pembelian (Y). Variabel celebrity endorser didefinisikan sebagai selebritis maupun tokoh yang berperan dalam periklanan untuk mempromosikan produk dalam rangka mempengaruhi keputusan pembelian (Bramantya \& Jatra, 2016). Variabel ini diukur berdasarkan indikator daya tarik, kepercayaan, dan keahlian (Sintani, 2016). Adapun variabel brand image atau citra merek didefinisikan sebagai persepsi konsumen tentang merek yang muncul dalam pikiran konsumen ketika mengingat merek tersebut (Schiffman \& Kanuk, 2008). Citra merek diukur berdasarkan indikator kekuatan, keunikan, dan keunggulan (Heda, 2017). Selanjutnya keputusan pembelian sebagai variabel terikat dijelaskan sebagai proses konsumen memilih suatu tindakan pembelian dari beberapa alternatif pilihan berdasarkan pertimbangan tertentu untuk memenuhi kebutuhannya (Schiffman \& Kanuk, 2008). Variabel keputusan pembelian diukur berdasarkan indikator tingkat kesesuaian kebutuhan dan keinginan konsumen, kualitas produk, pengaruh celebrity endorser dan citra merek dari produk (Kurniawan, 2018).

\section{Teknik Pengumpulan dan Analisis Data}

Data yang telah terkumpul melalui distribusi kuesioner secara online menggunalan google form selanjutnya diolah melalui aplikasi SPSS versi 25. Analisis regresi linier berganda digunakan sebagai teknik analisis data untuk menguji besarnya pengaruh antara dua variabel atau lebih dan mengetahui arah hubungan antara variabel independen $(\mathrm{X})$ dan variabel dependen (Y). Analisis regresi linier berganda dilakukan untuk mengetahui hubungan dan pengaruh antara celebrity endorser dan brand image terhadap keputusan pembelian produk Wardah pada mahasiswa di Fakultas Ekonomi Universitas Tidar. Analisis regresi linear berganda dapat dirumuskan melalui persamaan sebagai berikut:

Keterangan:

$$
\mathbf{Y}=\boldsymbol{\alpha}+\mathbf{b}_{1} \mathbf{X}_{1}+\mathbf{b}_{2} \mathbf{X}_{2}+e
$$

Y : Keputusan pembelian

a : Konstanta

$\mathrm{b}_{1}, \mathrm{~b}_{2}$ : Koefisien regresi

$\mathrm{X}_{1}$ : Celebrity endorser

$\mathrm{X}_{2}$ : Brand image

$e \quad$ : Standar kesalahan/error

\section{Hasil dan Pembahasan}

Hasil uji validitas dapat dilihat pada Tabel 2 sebagai berikut:

Tabel 2. Hasil Uji Validitas.

\begin{tabular}{|c|c|r|r|r|}
\hline Variabel & Item & r-hitung & r-tabel & Hasil \\
\hline \multirow{4}{*}{$\begin{array}{l}\text { Celebrity } \\
\text { endorser }\end{array}$} & $\mathrm{X} 1.1$ & 0,819 & 0,148 & \\
\cline { 2 - 4 } & $\mathrm{X} 1.2$ & 0,859 & 0,148 & \\
\cline { 2 - 4 } & $\mathrm{X} 1.3$ & 0,828 & 0,148 & \multirow{4}{*}{ Valid } \\
\cline { 2 - 4 } & $\mathrm{X} 1.4$ & 0,845 & 0,148 & \\
\cline { 2 - 4 } & $\mathrm{X} 1.5$ & 0,822 & 0,148 & \\
\cline { 2 - 4 } & $\mathrm{X} 1.6$ & 0,863 & 0,148 & \\
\hline
\end{tabular}




\begin{tabular}{|l|l|l|l|l|}
\hline \multirow{4}{*}{$\begin{array}{l}\text { Brand } \\
\text { image }\end{array}$} & $\mathrm{X} 2.1$ & 0,612 & 0,148 & \\
\cline { 2 - 4 } & $\mathrm{X} 2.2$ & 0,672 & 0,148 & \\
\cline { 2 - 4 } & $\mathrm{X} 2.3$ & 0,751 & 0,148 & \multirow{4}{*}{ Valid } \\
\cline { 2 - 4 } & $\mathrm{X} 2.4$ & 0,717 & 0,148 & \\
\cline { 2 - 4 } & $\mathrm{X} 2.5$ & 0,796 & 0,148 & \\
\cline { 2 - 4 } & $\mathrm{X} 2.6$ & 0,816 & 0,148 & \\
\hline \multirow{4}{*}{$\begin{array}{l}\text { Keputusan } \\
\text { Pembelian }\end{array}$} & $\mathrm{Y} 1.1$ & 0,736 & 0,148 & \multirow{4}{*}{ Valid } \\
\cline { 2 - 4 } & Y1.2 & 0,786 & 0,148 & \\
\cline { 2 - 4 } & Y1.3 & 0,661 & 0,148 & \\
\cline { 2 - 4 } & Y1.4 & 0,806 & 0,148 & \\
\hline
\end{tabular}

Sumber : data diolah

Hasil uji validitas berdasarkan data yang dipakai dalam penelitian sebanyak 175 responden, dengan nilai $r$-tabel untuk taraf signifikansi $5 \%(\alpha=0,05)$ dan dapat dicari berdasarkan pada jumlah responden atau N. Uji signifikansi dilakukan dengan cara membandingkan hasil nilai r-hitung dengan nilai r-table untuk $\mathrm{df}=\mathrm{N}-2$, sehingga $\mathrm{df}=175$ $2=173$. Untuk itu, r-tabel dengan df 173 dan alpha 0,05 yaitu sebesar 0,148 . Jika r-hitung lebih besar dari r-table dan bernilai positif, maka butir pertanyaan atau indikator dalam penelitian tersebut dinyatakan valid. Berdasarkan data r-hitung, hasil menunjukkan bahwa tidak ada satupun item yang memiliki $r<0,148$. Dengan demikian, dapat disimpulkan bahwa seluruh butir pertanyaan atau indikator yang digunakan dalam penelitian dinyatakan valid dan layak digunakan sebagai instrumen dalam penelitian.

Selanjutnya, hasil uji reliabilitas Cronbach's Alpha dapat dilihat pada Tabel 3 yang menunjukkan bahwa semua variabel dinyatakan reliabel karena nilai Cronbach's Alpha > 0,60, artinya jawaban dari responden reliabel atau konsisten.

Tabel 3. Hasil Uji Reliabilitas.

\begin{tabular}{|l|r|c|}
\hline \multicolumn{1}{|c|}{ Variabel } & Cronbach's Alpha & Hasil \\
\hline Celebrity endorser & 0,915 & Reliabel \\
\hline Brand image & 0,819 & Reliabel \\
\hline Keputusan Pembelian & 0,722 & Reliabel \\
\hline
\end{tabular}

Sumber : data diolah

Adapun model persamaan regresi linear berdasarkan hasil uji regresi linier berganda dapat disusun sebagai berikut:

Tabel 4. Hasil Analisis Regresi Linier Berganda.

\begin{tabular}{|l|l|r|r|r|r|r|}
\hline \multicolumn{2}{|c|}{ Coefficients $^{\mathbf{a}}$} \\
\hline \multirow{2}{*}{ Model } & \multicolumn{2}{|c|}{$\begin{array}{c}\text { Unstandardized } \\
\text { Coefficients }\end{array}$} & $\begin{array}{c}\text { Standardized } \\
\text { Coefficients }\end{array}$ & \multirow{2}{*}{ Sig. } & \\
\cline { 3 - 7 } \multicolumn{2}{|c|}{} & \multicolumn{1}{|c|}{ B } & Std. Error & Beta & & \\
\hline \multirow{3}{*}{1} & (Constant) & 1.351 & .847 & & 1.596 & .112 \\
\cline { 2 - 7 } & Celebrity endorser & .173 & .042 & .282 & 4.156 & .000 \\
\cline { 2 - 7 } & Brand image & .369 & .051 & .493 & 7.273 & .000 \\
\hline
\end{tabular}

a. Dependent Variable: Keputusan Pembelian

Sumber: data diolah 


$$
\begin{aligned}
Y & =\alpha+b_{1} X_{1}+b_{2} X_{2}+e \\
& =1,351+0,173 X_{1}+0,369 X_{2}+e
\end{aligned}
$$

Dari hasil persamaan tersebut, diartikan bahwa nilai a sebesar 1,351 adalah konstanta atau keadaan ketika variabel keputusan pembelian belum dipengaruhi oleh variabel lain yaitu variabel celebrity endorser (X1) dan variabel brand image (X2). Jika variabel independen tidak ada maka variabel keputusan pembelian tidak akan mengalami perubahan. B1 (nilai koefisien regresi X1) sebesar 0,173, menunjukkan bahwa variabel celebrity endorser mempunyai pengaruh positif terhadap keputusan pembelian yang artinya bahwa setiap kenaikan 1 satuan variabel celebrity endorser maka akan mempengaruhi keputusan pembelian sebesar 0,173. Dengan asumsi bahwa dalam penelitian ini variabel lain tidak diteliti. Sementara B2 sebesar 0,369 menunjukkan bahwa variabel brand image mempunyai pengaruh yang positif terhadap keputusan pembelian artinya setiap kenaikan 1 satuan variabel brand image maka akan mempengaruhi keputusan pembelian sebesar 0,369.

Adapun Uji T adalah teknik analisis untuk menguji signifikansi koefisien parsial regresi variabel bebas secara individu yang ada didalam model terhadap variabel terikat. Jika signifikansi lebih dari 0,05 maka beberapa variabel bebas akan memiliki pengaruh yang signifikan terhadap variabel terikat. Berdasarkan hasil pada Tabel 4, hasil pengujian hipotesis secara parsial atau individu (uji T) menunjukkan bahwa:

1. Nilai signifikansi pengaruh variabel celebrity endorser (X1) terhadap keputusan pembelian (Y) sebesar 0,000 atau lebih kecil dari 0,05 dan koefisien regresi bernilai positif sebesar 0,173 . Sedangkan nilai t hitung yang diperoleh variabel celebrity endorser sebesar 4,156 lebih besar dari t tabel yaitu 1,97385. Berdasarkan hasil tersebut dapat disimpulan bahwa celebrity endorser berpengaruh secara positif dan signifikan terhadap keputusan pembelian produk Wardah pada mahasiswa di Fakultas Ekonomi Universitas Tidar. Hasil ini mendukung hasil penelitian terdahulu yang menjelaskan bahwa penggunaan celebrity endorser dapat meningkatkan keputusan pembelian konsumen terhadap produk yang dipasarkan perusahaan (Mubarak et al., 2018).

2. Nilai signifikansi pengaruh variabel brand image (X2) terhadap keputusan pembelian (Y) sebesar 0,000 atau lebih kecil dari 0,05 dan koefisien regresi bernilai positif sebesar 0,369. Sedangkan nilai t-hitung yang didapat variabel brand image sebesar 7,273 lebih besar dari t-tabel yaitu 1,97385. Dengan demikian brand image dibuktikan berpengaruh secara parsial terhadap terhadap keputusan pembelian produk Wardah pada mahasiswa di Fakultas Ekonomi Universitas Tidar. Dalam hal ini, brand image mampu memberikan pengaruh positif terhadap keputusan pembelian secara signifikan. Hasil ini mendukung penelitian terdahulu yang menjelaskan bahwa citra merek, citra produk, maupun citra dari perusahaan yang baik dapat meningkatkan minat beli konsumen sehingga konsumen cenderung memutuskan untuk membeli produk dari merek yang citranya baik (Nuraini \& Mudiantono, 2017).

\begin{tabular}{|c|c|c|c|c|c|c|}
\hline \multicolumn{7}{|c|}{ ANOVA $^{\mathbf{a}}$} \\
\hline \multicolumn{2}{|c|}{ Model } & Sum of Squares & $\mathrm{df}$ & Mean Square & $\mathrm{F}$ & Sig. \\
\hline \multirow[t]{3}{*}{1} & Regression & 415.425 & 2 & 207.712 & 81.477 & $.000^{\mathrm{b}}$ \\
\hline & Residual & 438.484 & 172 & 2.549 & & \\
\hline & Total & 853.909 & 174 & & & \\
\hline \multicolumn{7}{|c|}{ a. Dependent Variable: Keputusan Pembelian } \\
\hline
\end{tabular}

Tabel 5. Hasil Uji F.

Sumber: data diolah 
Uji $F$ adalah teknik analisis untuk menguji apakah seluruh variabel bebas dapat mempengaruhi variabel terikat secara bersamaan atau simultan. Hasil uji $\mathrm{F}$ yang ditunjukkan pada Tabel 5, didapatkan nilai F hitung sebesar 81,477 lebih besar dari F tabel yaitu 3,769138 dengan nilai signifikansi sebesar 0,000 lebih kecil dari 0,05. Berdasarkan hasil tersebut maka celebrity endorser dan brand image dibuktikan berpengaruh secara simultan terhadap keputusan pembelian produk Wardah pada mahasiswa di Fakultas Ekonomi Universitas Tidar. Dalam hal ini celebrity endorser dan brand image secara bersamaan berpengaruh positif dan signifikan terhadap keputusan pembelian produk Wardah. Hasil ini mendukung penelitian terdahulu yang menjelaskan bahwa secara simultan variabel celebrity endorser dan brand image berpengaruh pada keputusan pembelian (Dewi, 2019; Heda, 2017).

Tabel 6. Hasil Uji Koefisien Determinasi.

\begin{tabular}{|l|c|c|c|c|}
\hline \multicolumn{5}{|c|}{ Model Summary $^{\mathbf{b}}$} \\
\hline Model & $\mathrm{R}$ & R Square & $\begin{array}{c}\text { Adjusted R } \\
\text { Square }\end{array}$ & $\begin{array}{c}\text { Std. Error of the } \\
\text { Estimate }\end{array}$ \\
\hline 1 & $.697^{\mathrm{a}}$ & .486 & .481 & 1.597 \\
\hline \multicolumn{4}{|l|}{ a. Predictors: (Constant), Brand image, Celebrity endorser } \\
\hline
\end{tabular}

Sumber: data diolah

Adapun hasil uji koefisien determinasi (R2) berdasarkan Tabel 6 menunjukkan bahwa nilai koefisien R-Square (R2) sebesar 0,486 atau 48,6\% yang artinya besar pengaruh variabel celebrity endorser (X1) dan brand image (X2) secara simultan terhadap keputusan pembelian (Y) adalah sebesar 48,6\%, sedangkan besarnya variabel lain yang mempengaruhi variabel keputusan pembelian tetapi tidak dimasukkan dalam model yaitu sebesar $51,4 \%$ diperoleh dari $100 \%-48,6 \%$.

Hasil penelitian menunjukkan bahwa terdapat pengaruh yang positif dan signifikan dari variabel celebrity endorser terhadap variabel keputusan pembelian produk Wardah pada mahasiswa di Fakultas Ekonomi Universitas Tidar. Dengan demikian, celebrity endorser yang digunakan oleh Wardah dalam mempromosikan produknya telah mampu meningkatkan keputusan konsumen untuk membeli produk Wardah. Hasil tersebut sesuai dengan penelitian terdahulu yang menunjukkan pengaruh positif dan signifikan (Mubarak et al., 2018). Walaupun demikian, hasil ini tidak mendukung penelitian terdahulu yang menyatakan bahwa pengaruhnya tidak signifikan (Novianti, 2020). Hasil penelitian ini diharapkan dapat menjadi referensi bagi penelitian selanjutnya untuk menguji hubungan antara celebrity endorser dan keputusan pembelian konsumen. Melalui hasil penelitian, dapat diketahui bahwa persepsi konsumen tentang produk yang ditawarkan oleh selebriti berdampak pada keputusan pembelian konsumen. Jika suatu produk ditawarkan oleh selebriti yang memiliki daya tarik fisik maupun kepribadian, dapat dipercaya, dan ahli atau memiliki product knowledge yang baik, maka produk tersebut cenderung diminati konsumen sehingga konsumen memutuskan untuk membeli produk yang dipromosikan oleh selebriti tersebut. Celebrity endorsement memiliki pengaruh yang signifikan dalam membentuk persepsi atau cara konsumen memandang suatu produk melalui iklan. Dengan adanya celebrity endorsers maka pesan dari iklan tersebut akan semakin mudah diterima konsumen, sehingga semakin baik celebrity endorsers yang digunakan maka akan semakin mempengaruhi keputusan pembelian konsumen terhadap produk. 


\section{Dewi Rosita, Ivo Novitaningtyas}

Hasil penelitian juga menunjukkan bahwa terdapat pengaruh yang positif dan signifikan dari variabel brand image terhadap variabel keputusan pembelian produk Wardah pada mahasiswa di Fakultas Ekonomi Universitas Tidar. Dengan demikian, Wardah telah memiliki citra merek yang baik dalam persepsi konsumennya. Lebih lanjut, citra merek yang dimiliki Wardah telah mampu meningkatkan keputusan konsumen untuk membeli produk Wardah dibandingkan dengan produk kosmetik dari merek lainnya. Hasil penelitian sesuai dengan hasil penelitian terdahulu yang menyatakan bahwa semakin baik citra dari suatu merek maka akan semakin meningkat minat konsumen untuk memutuskan membeli produk tersebut (Dewi, 2019; Heda, 2017). Brand image dapat mencerminkan penilaian konsumen terhadap karakteristik produk, sehingga brand image yang bagus mampu memberikan pengaruh kepada sikap konsumen saat mengambil keputusan pembelian terhadap produk. Dalam menghadapi persaingan bisnis yang kompetitif, perusahaan harus mampu beradaptasi dan terus menerus mentranformasikan produknya dalam menciptakan citra merek atau brand image yang bagus di benak konsumen. Oleh karena itu, dengan adanya brand image yang baik bisa meningkatkan kepuasan konsumen dan mampu menciptakan konsumen yang loyal walaupun banyak brand baru yang bermunculan dari para kompetitornya.

\section{Kesimpulan}

Hasil penelitian menunjukkan bahwa celebrity endorser dan brand image memiliki pengaruh yang positif dan signifikan terhadap keputusan pembelian produk Wardah pada mahasiswa di Fakultas Ekonomi Universitas Tidar baik secara parsial dan simultan. Hasil menunjukkan bahwa penggunaan celebrity endorser yang menarik, dapat dipercaya, dan memiliki pengetahuan terhadap produk (product knowledge) dapat meyakinkan konsumen untuk memutuskan membeli produk yang ditawarkan. Selain itu, jika suatu produk memiliki merek dengan citra yang baik atau positif dalam persepsi konsumen, maka konsumen tersebut cenderung memutuskan untuk membeli produk dengan citra merek yang baik dibandingkan merek lainnya. Hasil penelitian dapat menjadi bahan evaluasi bagi penerapan strategi penggunaan celebrity endorser dan peningkatan citra merek oleh Wardah yang menunjukkan hasil efektif dalam meningkatkan keputusan pembelian konsumen. Hasil ini memberikan implikasi manajerial bagi perusahaan kosmetik untuk menggunakan strategi celebrity endorser dan meningkatkan citra merek dari produknya sehingga diharapkan dapat meningkatkan keputusan pembelian konsumen terhadap produknya. Selain itu, hasil penelitian juga dapat menjadi referensi bagi peneliti selanjutnya dalam mengembangkan model penelitian dan variabel-variabel yang dapat mempengaruhi keputusan pembelian konsumen terhadap produk kosmetik pada konsumen mahasiswa.

\section{Daftar Pustaka}

Ahmadi, A. S., Budiarto, W., \& Indrawati, M. (2018). Pengaruh Kualitas Produk dan Kepercayaan Pelanggan Terhadap Kepuasan Pelanggan Pada PT PAL Indonesia (Persero) Surabaya Melalui Keputusan Pembelian. Jurnal Manajerial Bisnis, 1(2), 112-124.

Arief, M. (2017). Analisis Faktor-Faktor Yang Mempengaruhi Minat Beli Kosmetik Pria Pada Mahasiswa Fakultas Ekonomi Dan Bisnis Universitas Brawijaya (Studi Kasus pada Mahasiwa S1 Prodi Ekonomi Islam Fakultas Ekonomi dan Bisnis Universitas Brawijaya). Universitas Brawijaya.

Bramantya, Y., \& Jatra, I. (2016). Pengaruh Celebrity Endorser Dan Brand Image Terhadap Keputusan Pembelian Yamaha Jupiter Mx Di Kota Denpasar. E-Jurnal Manajemen Universitas Udayana, 5(3), 255237. 
Dewi, R. N. T. (2019). Pengaruh Kualitas Produk, Citra Merek Dan Celebrity Endorser Terhadap Keputusan Pembelian Smarthphone Melalui Minat Beli Sebagai Variabel Intervening. Ejournal Administrasi Bisnis, 7(4, 2019), 414.

Fitrianna, H., \& Aurinawati, D. (2020). Pengaruh Digital Marketing Pada Peningkatan Brand Awareness Dan Brand Image Terhadap Keputusan Pembelian Produk Cokelat Monggo di Yogyakarta. INOBIS: Jurnal Inovasi Bisnis Dan Manajemen Indonesia, 3(3), 409-418. https://doi.org/10.31842/jurnalinobis.v3i3.147

Haryani, I., \& Herwanto, J. (2015). Hubungan Konformitas dan Kontrol Diri Dengan Perilaku Konsumtif Terhadap Produk Kosmetik pada Mahasiswi. Jurnal Psikologi UIN Sultan Syarif Kasim Riau, 11(1), 5-11.

Heda, N. (2017). Pengaruh Celebrity Endorser dan Brand Image Terhadap Keputusan Pembelian Sampo (Studi Kasus pada Merek Clear). In Skripsi.

Kotler, P., \& Keller, K. L. (2018). Manajemen Pemasaran Edisi Kedua Belas Jilid 1 (12th ed.). Jakarta: Indeks.

Kurniawan, D. (2018). Pengaruh Citra Merek terhadap Keputusan Pembelian. Administrasi Bisnis, 56(1), 75-81.

Mubarak, N., DH, A. F., \& Nuralam, I. P. (2018). Pengaruh Celebrity Endorser Pada Media Sosial Instagram Terhadap Keputusan Pembelian (Survei Online pada Konsumen Produk Erigo Jakarta melalui Instagram). Jurnal Administrasi Bisnis (JAB), 62(1), 18-25.

Negara, A. A. N. D. ., Arifiin, Z., \& Nuralam, I. P. (2018). Pengaruh Kualitas Produk dan Brand Image Terhadap Minat Beli (Survei Pada Pembeli Di Gerai Starbucks Di Kota Surabaya). Jurnal Administrasi Bisnis (JAB), 61(2), 202-209.

Novianti, T. A. (2020). Pengaruh Celebrity Endorser dan Kualitas Produk terhadap Keputusan Pembelian dengan Citra Merek sebagai Variabel Intervening. Jurnal Manajemen Dan Bisnis, 1(2018), 43-50.

Nuraini, I. S., \& Mudiantono. (2017). Faktor-Faktor yang Mempengaruhi Kepuasan Pelanggan Serta Dampaknya Terhadap Minat Beli Ulang Situs Traveloka (Studi pada konsumen Traveloka di kota Semarang). Diponegoro Journal Of Management, 6(4), 1-11.

Nurhalim, A. D. (2021). Analisis Pergeseran Perilaku Konsumen Dalam Niat Beli Di Sektor Otomotif E-Commerce Indonesia. Jurnal Bina Manajemen, 9(2), 113-125.

Priyono, D. E. (2015). The Effect of Celebrity Endorsement, Trust, Brand Image on Purchase Intention of Maybelline Cosmetic in Surabaya. Perbanas.

Rizky, S., \& Ilhami, N. U. R. (2018). Pengaruh Celebrity Endorser Dan Citra Merek Dalam Iklan Terhadap Keputusan Pembelian (Studi Kasus Pada Kerudung Zoya Pada Outlet Zoya Purwokerto). Institut Agama Islam Negeri.

Schiffman, L., \& Kanuk, L. L. (2008). Perilaku Konsumen. Jakarta: PT Indeks.

Sekaran, U. (2003). Research Method for Business, 4th edition. New York: John Wiley and Sons, Inc.

Sintani, L. (2016). Pengaruh Penggunaan Celebrity Endorser Isyana vs Gangster' Terhadap Brand Awareness Masyarakat Surabaya. Jurnal E-Komunikasi, 4(1), 1-10.

Sugiyono. (2013). Metode Penelitian Bisnis (Pendekatan Kuantitatif, Kualitatif dan R\&D). Bandung: Penerbit Alfabeta.

Tjiptono, F., \& Chandra, G. (2017). Pemasaran Strategik Edisi 3. Yogyakarta: Penerbit Andi. Yuliana, pramudi riski. (2015). Pengaruh Gaya Hidup Konsumtif Dan Kelompok Referensi. Jurnal Riset Ekonomi Dan Manajemen, 15(2), 280-301. 